\title{
Influence of Revenue Mobilization Practices on Service Delivery in Decentralized Governments: The Case of District Assemblies in Ghana
}

\author{
George Kojo Scott \\ Secretary General, African Association for Public Administration and Management \\ (AAPAM), P.O. Box 48677 -00100, Nairobi, Kenya \\ E-mail: g.k.ssccott@gmail.com
}

Received: Nov. 18, 2018 Accepted: Dec. 3, 2018 Online published: Dec. 9, 2018

doi:10.5296/jpag.v8i4.13926 URL: https://doi.org/10.5296/jpag.v8i4.13926

\begin{abstract}
This study analyzed how revenue mobilization practices in the District Assemblies (DAs) of Ghana influence service delivery. The research adopted the mixed methods research design and gathered qualitative and quantitative data using questionnaires, interviews, focus group discussions and document analysis. Multi-stage sampling method where thirty four out of 170 districts were selected from which the study sampled 612 DA officials and 1020 citizens who responded to questionnaires. The sample also included 28 key interview informants and 20 participants in two focus group discussions. The study analyzed quantitative data using descriptive statistics and regression, while qualitative data were interpreted thematically. The study established that revenue mobilization practices at the DAs had a positive and significant effect on service delivery. The study recommends that the DA authorities should audit and review automated revenue collection tools to ensure optimal benefits from these automations. The parliament and District Assemblies are encouraged to review and consolidate the existing financial management legal framework to ensure faster transfer of funds to the district assemblies and specify sanctions on national government officials who mishandle or delay the funds.
\end{abstract}

Keywords: public financial management, equity, revenue mobilization, service delivery

\section{Introduction}

Decentralized governments are essentially created to serve as partners to the central government in the national development and, as partners they are required to provide administrative, fiscal, and other public services and amenities to residents (Adu-Gyamfi, 2014). In effect, it is the responsibility of decentralized government units to provide services 
as specified in the constitution and the laws operationalizing these decentralized government units. The provision of these services requires enough financial resources and therefore render revenue mobilization critically paramount among the decentralized governments units such as the District Assemblies (DAs) in Ghana (Scott, 2016).

Oates (1998) while emphasizing the importance of revenue mobilization in decentralized units argues that, apart from raising revenues, localized revenue mobilization has the potential to foster political and administrative accountability by empowering the communities. In turn Baumann (2000) notes that successful decentralization needs to give scope and resources for the contribution to development by all actors. Like Baumann, Oyugi (2000) points out that in many countries, the decentralized governments act as a tier of government requiring adequate finances to enable them cope with numerous developmental activities within their jurisdiction.

Sound revenue system for local governments is an essential pre-condition for the success of fiscal decentralization. Akpa (2008) observes that revenue is a necessary tool for the effective functioning of any government machinery which guarantees survival of government agencies. Bhatia (2009) on the other hand, posit that tax is a compulsory levy and that taxpayers are under obligation to pay the sums irrespective of any corresponding return of services or goods. Furtherance to Akpa's position, Thies (2010) and Salami (2011) indicate that taxation is the primary mechanism of revenue mobilization for governments while Portillo and Block (2012) add further that taxes are coercive in nature and are an involuntary trade of a taxpayer's resources, for public goods or services.

In a more comprehensive stance, Adu-Gyamfi (2014) defined revenue mobilization as the act of marshaling, assembling, and organizing financial contributions from all incomes accruing from identifiable sources in an economic setting. Scott (2016) identified revenue mobilization as one of the six key sub components of public financial management, and indicates that; planning/budgeting, revenue mobilization, expenditure/payment, financial/accounting reporting, auditing and PFM regulatory framework practices exist as a system of inter-related elements which has the tendency to impact or influence each other and consequently, service delivery.

Despite the overriding importance of the need for revenue, decentralized authorities contend with limited internal revenue generation, remaining overwhelmingly dependent on central government for its financial resources (Rakner, 2001). Given the limited internal revenue raising ability, Bird and Slack (2010) argued that sound revenue mobilization practices for decentralized government units are an essential pre-condition for the success of fiscal decentralization. The decentralized units therefore need to carefully implement practical and revenue generation mechanisms which are acceptable to the residents (Finch, 2015).

In general, there are two main categories of revenue for decentralized government units in Africa - internally generated revenues and external transfers. Own revenue or internally generated revenue includes taxes, user fees, property rates and various licenses (Smoke, 2001). However, such local taxation is limited, according to Nkrumah (2000) who contended that the lucrative tax fields for example, income tax, sales tax, import and export duties, all belong to the central government while local governments have access only to low yielding 
taxes such as basic rates and market tolls.

Fjeldstad, Chambas and Brun (2014) explained that some taxes and fees are collected by the government and channeled back to the local government. For instance, in Malawi non-tax revenue such as passport fees are collected by the central government and then redistributed to local authorities using a formula approved by the cabinet. There are also the cases where collection of many local government revenue sources has been outsourced in recent years, citing Tanzania. They include private collection of property taxes in some urban councils. There are also cases where revenue collection is outsourced to a range of different types of agents within the local authority as in the case Dar es Salam, Mwanza and Moshi local authorities in Tanzania. In Dar es Salam, parking fees collection was outsourced to Ubungo Bus Service; in Mwanza the collection of fish market fees was outsourced to a fish dealer organization and in Moshi a coffee cooperative collected taxes on agricultural products in the region (Mrutu \& Mganga, 2016).

A widely found feature in decentralized internal revenue mobilization practices is the huge number of revenue instruments used by local authorities (Fjeldstad \& Semboja, 2000). Local governments seem to raise whatever taxes, fees, and charges they can, often without worrying about the economic distortions and distribution effects that these taxation instruments may create. Bardhan and Mookherjee (2002) argued that a complicated local government revenue system is costly to administer and can lead to corruption and mismanagement. Moreover, many local taxes distort resource allocation decisions, and inhibit the start-up of new enterprises and the achievement of economic growth (Fjeldstad \& Therkildsen, 2008; Misch Koh \& Paustian, 2011).

Decentralized units also get revenue through external transfers from the central or regional levels, usually in the form of grants and mandatory revenue sharing arrangements (Bahl, 1999). African governments have established various formula for revenue sharing systems to ensure that central resource allocation decisions are unaffected by political considerations (Bahl \& Smoke 2003). Ghana is a pioneer in its formula-based system of financial transfers for local development from the central government through the District Assemblies Common Fund (DACF) established in 1994 whereas South Africa's Local Government Equitable Share was established in 1997 (Chitiga-Mabugu \& Monkam, 2013).

In Kenya, the Local Authority Transfer Fund (LATF) was established in 1999 and later reviewed in 2013 in line with devolved governments established under the 2010 constitution (Finch, 2015). Chapter 12 of the Kenyan Constitution on finances provides for mandatory funding of the devolved units which should be at least 15 percent of total national revenue as per the latest audited accounts of national revenues. The constitution also established an equalization fund equivalent to one half percent $(0.5 \%)$ of the national revenues for devolved units marked as marginalized counties and sublocations (Chitere \& Ngundo, 2015; Koskei, 2018). Nigeria's Federation Account created in 1999 is another prominent formula-based system of intergovernmental transfers (Ojide, 2015).

There are other revenue sources which are available at sub national level including external financial contributions which provide considerable funding to the constituencies at village 
and local level in some countries. These sources are dominated by aid projects or programmes funded by a mix of international non-governmental organizations, bilateral and multilateral donors (Fjeldstad 2001; Yatta \& Vaillancourt 2010). In many rural areas, various forms of self-help activities also count as a resource for decentralized units, as they contribute to the maintenance of public services such as village roads, primary schools and health facilities. In addition, Yatta and Vaillancourt (2010) observe that in some countries decentralized government units are given the right to borrow to finance investments in local capital infrastructure.

Ghana's DAs have three sources of revenue - the District Assemblies' Common Fund, ceded revenue and their own revenue-raising powers through local taxation (Nkrumah, 2000). Ceded revenue from several smaller tax fields such as betting and adverts taxes, is collected by the Ghanaian Internal Revenue Service (IRS), but then transferred to DAs via the Ministry of Local Government and Rural Development (Botchie, 2000). There is mixed evidence of its workings with Nkrumah (2000) suggesting that ceded revenue has contributed quite substantial sums to local governments, yet Ayee (2000) cites evidence from his three case-study districts that none had actually received such disbursements from central government. Additionally, Mogues and Benin (2012) find that intergovernmental grants, the flow of all grants taken together discourage, rather than encourage the collection of internally generated revenues.

Given the extensive responsibilities allocated to district authorities, multilateral organizations, scholars and practitioners have consistently observed that the financial position of District Authorities is vulnerable. Local governments have little fiscal independence, remaining overwhelmingly dependent on central government for its financial resources, with limited revenue raising ability. Further, Oyugi (2000) suggested that the dependence of local authorities on central government funding leads to a loss of operational autonomy, with local initiatives undermined which in turn affects development projects and service delivery to the citizens. However, Finch (2015) observes that the entrenchment of the revenue sharing formulas in the constitution of the countries which have adopted decentralization is an advance in this respect, providing a constitutionally guaranteed minimum.

Despite, turning to decentralization, many African governments have been faced with a governance crisis and poor service delivery capability. Ola and Tonwe (2005) suggest that lack of finance remains a major challenge to the success of devolution in many African countries. The devolution of revenue mobilization and spending powers to lower levels of government in turn has had its share of challenges (Fjeldstad \& Heggstad, 2012). Fosu and Ashiagbor (2012) posited that many of the devolved units are financially weak and rely on financial transfers and assistance from the central government. Many of the devolved units are faced by the challenges of mobilizing appropriate levels of revenue to enable effective service provision and address poverty and inequality issues at the local level (Latema, 2013).

\section{Problem Analysis}

Several authors (Adu-Gyamfi, 2014; Fjeldstad et al., 2014; Fosu \& Ashiagbor, 2012; Mrutu \& Mganga, 2016) have noted that many localized revenue mobilization activities and systems 
in Africa are characterized by high levels of complexities, arbitrariness, coercion and corruption thus resistance and low levels of compliance. This in turn affects the amount of revenue generated from various internal sources for use by decentralized government units. On the basis of the systems theory, Oduro (2003) and Robert (2003) argued that the various components of public financial management practices do not meet the rules of interrelatedness amongst themselves and in relation to service delivery. These weak links of PFM practices at the District Assemblies level which are also manifest at the national level, consequently lead to allocative inefficiencies. It could be inferred that lack of interrelatedness with revenue mobilization practices could create difficulties for other aspect of PFM such as the budget, expenditure and even the accounting practices.

Despite several reforms in public administration on the basis of the New Public Management theory, there have been challenges in adopting most business/market oriented financial management practices due to the unique characteristics of public sector entities' operating environment. Mogues and Benin (2012) found difficulties in institutionalizing effective mechanisms in the District Assemblies for effective revenue generation. Additionally, Hamid (2013) flags challenges in hiring and retaining staff at the local level to perform the technical functions including that of efficient revenue mobilization.

The transaction cost theory holds that there exist motivation, coordination and control costs which if not well managed could adversely influence public financial management practices and their role in service delivery. For example, Khan and Hildreth (2004) identify motivational costs associated with encouraging revenue collection agents and procurement officers to desist from cheating or colluding with traders and suppliers. Coordination and control costs could also occur throughout the public financial transactions, including revenue mobilization, as a result of efforts to manage the various players involved in service delivery activities. Such coordination and control costs manifest through disputes such as strikes by employees, and untimely payments (Buertey, Miezah, \& Adjei-Kumi, 2013).

There also exist agency problems in the public financial management practices and in the quest by decentralized entities to deliver satisfactory services to citizens. Leruth and Paul (2006) highlighted detrimental opportunistic behaviors by public officers and suppliers especially in revenue mobilization. Pauw et al (2010) also identified principal-agent tensions between central and decentralized governments especially about transfer of funds needed for service provision. According to Afoom (2011), providers of external funds such as donors and banks also exert undue pressure on the district assemblies as they seek to obtain maximum benefits for themselves at the detriment of service delivery. The overreliance on external sources of finances stifles internal revenue generation capabilities of the DAs. Further, such external funds tend to have attached conditionalities which do not match local priorities and needs of citizens.

Most importantly, the Auditor General's reports from 1997 up to 2014 have identified a trend of financial malpractices including outright thefts, embezzlements, misappropriation and misapplication of various funds including internally generated funds and the District Assemblies Common Fund. The Auditor General reports highlight weak internal revenue 
generation, for instance, indicating that in 2013/2014 period, the DAs internally generated revenues accounted for only $19.5 \%$ of total revenues.

Given the importance of revenue mobilization for the decentralized governments whose primary objectives is to provide better services to the citizens, and the outstanding issues identified in the problem analysis, this study assessed the influence of revenue mobilization practices on service delivery in the District Assemblies of Ghana.

\section{Literature Review}

Narrowing down to decentralized units, Smoke (2001) specified that financial responsibility and consequent service delivery are core interlinked components of decentralization, and that if local governments are to carry out and deliver services efficiently, they must have adequate revenues; raised locally or transferred from central government, as well as the authority to make expenditure decisions. Rosen (2004) further explained that those responsibilities can take various forms including self-financing, or cost recovery through user charges, co-financing or co-production which users participate in providing services through monetary or labor contributions. Further, the responsibilities involve intergovernmental transfers of general revenues from taxes collected by central government to local government for general or specific uses, as well as municipal borrowing and acquisition of resources through loan guarantees.

Crook and Manor (1998) contended that, being closer to the people, local authorities are more capable and can more easily identify the needs of the people and thus supply the appropriate form and supply of public services. Livingstone and Charlton (1998) relate the above contentions to financial management and argue that communities are willing to pay local taxes where the amounts they contribute can be related more directly to services received. As a result, it is expected that the level of tax revenue could be increased without much public dissatisfaction (Olowu, 2002).

Offering further clarification, Khan and Hildreth (2004) indicates that the transaction cost theory could be applied to many fields of public financial management. Hyman (2013) corroborate Khan and Hildreth (2004) indicating that any issue that can be posed directly or indirectly as a contracting issue could be addressed in transaction management terms. Several suggestions have been made aimed at efficient revenue mobilization practices. For example, in line with the transaction cost framework, Cosgel and Miceli (2009) indicated that revenue could be mobilized under three arrangements - wage contract, share contract and fixed rent contract. Wage contract, entails that the revenue authority hires the revenue collectors on fixed wages. The collection agent returns over to the collection authority all the revenue collected and is paid the fixed wages. Unlike the wage contract, share contract occurs where, in lieu of the wages, the revenue collection agents are allocated specified share of the revenues collected. In the case of the fixed rent, the revenue collectors agree to pay a specified fixed sum to the collection authority in return for their right to the entire revenue proceeds (Jang \& Eger, 2018). The impression here is that, depending on the particular circumstances, the transaction cost of a specific contract could be more efficient than the other types of contract. 
In terms of cost effectiveness and the allocative efficiency theory, Rao and Das Gupta (1995) explain that federal transfers to local government units could act as means of enabling poorer regions to undertake nationally optimal levels of poverty alleviation. For example, it is stated that federal transfer in a fiscally decentralized structure of government can act as an instrument to bring about greater redistributive justice between the rich and poor regions, and enhances more equitable sharing of resources among jurisdictions (Rao \& Das-Gupta, 1995). Smoke (2001) further explains that certain capital-intensive services such as electricity, utilities and transportation systems may exhibit economies of scale in production. In such cases it is more efficient to provide services on a larger scale and over a wider area at the national level.

The resource based view theoretical perspective has also been applied to studies of revenue mobilization in the decentralized authorities. The resource based view posits that entities such as decentralized governments possess unique resources which they can harness to build their competitive advantage. Competitive advantage among public sector entities is viewed in the service delivery lenses (Kimutai, 2017). Mrutu and Mganga (2016) applied the theory in analyzing the performance of outsource revenue collection services among local authorities in Tanzania and thus this theory was found appropriate in attempts to understand the link between revenue mobilization and service delivery in the District Assemblies of Ghana.

Torome (2013) had also applied the theory of optimal taxation which holds that a tax system should be chosen to maximize a social welfare function subject to a set of constraints. According to the theory, the social welfare function is based on the utilities of individuals in the societies. This theory was similar to arguments regarding philosophy of equity as advanced by Scott (2016). Scott (2016) held that activities such as localized revenue mobilization under fiscal decentralization should be aimed at improving access and distribution equity and enhancing inclusion.

\section{Empirical Review}

Akudugu and Oppong-Peprah (2013) collected primary (interviews and group discussion) and secondary data from DAs trial balance to study the revenue mobilization and management in the Asante Akim South District Assembly. The study found that there were limited internally generated funds which were used for recurrent expenditures such as personnel emoluments, travel and transport. Adu-Gyamfi (2014) in a study of Upper Denkyira East Municipal Assembly revenue mobilization practices found that the weak internal revenue collection in the DAs is as a result of inadequate data on revenue sources, lack of enforcement of revenue mobilization bye laws, inadequate revenue collectors and poor training of the revenue collectors. Akorsu (2015) made similar finding in a study in Cape Coast Metropolitan Assembly.

In Kenya, Torome (2013) used inferential regression using 10 year (2002-2012) secondary data on internally generated revenues, borrowings and national government transfers to investigate the relationship between revenue mobilization and performance of local authorities in Kenya. Local government performance was measured in terms of performance evaluation scores from the local authorities' performance contracting. Torome found that internally generated revenues $(\beta=3.231 ; p<0.05)$ and national government transfers $(\beta$ 
$=6.0212 ; \mathrm{p}<0.05)$ had significant positive relationship with local authorities' performance while borrowings by the local authorities had a positive but insignificant link to performance $(\beta=13.2195 ; \mathrm{p}>0.05)$.

In another study in Kenya, Otieno, Odundo and Rambo (2014) provided empirical evidence on influence of Local Authority Transfer Fund (LATF) on service delivery by local government authorities in Kenya. The study applied cross-sectional survey design where household heads and market traders in Siaya County in Kenya were the target population. The study found implications that the disbursement of LATF resources to Siaya Municipal Council for over ten years had not contributed to improved delivery of essential services. The study found that there was no change in water provision and adequacy had no change while garbage collection and sewerage services had deteriorated even with LATF resources. This was a departure from Torome (2013) findings. Further, it emerged that service delivery is constrained by political leaders' interference, non-adherence to public procurement regulations and understaffing.

\section{Conceptual Framework}

Based on the foregoing discussions, a conceptual framework for revenue mobilization and service delivery (Figure 1) was developed to show the link between revenue mobilization practices and service delivery as applicable for decentralized governments. The framework holds that revenue mobilization practices as indicated by policies, procedures, sources of revenues, cost effectiveness and adequacy of the revenues mobilized have a role to play towards the services offered by the DAs. The indicators for service delivery by public entities are borrowed from Scott (2018) who identified availability, quality and the cost of these services as well citizens' satisfaction levels as reliable measures of service delivery. In line with the systems approach, the conceptual framework emphasizes the inter-linkages among the issues studied.

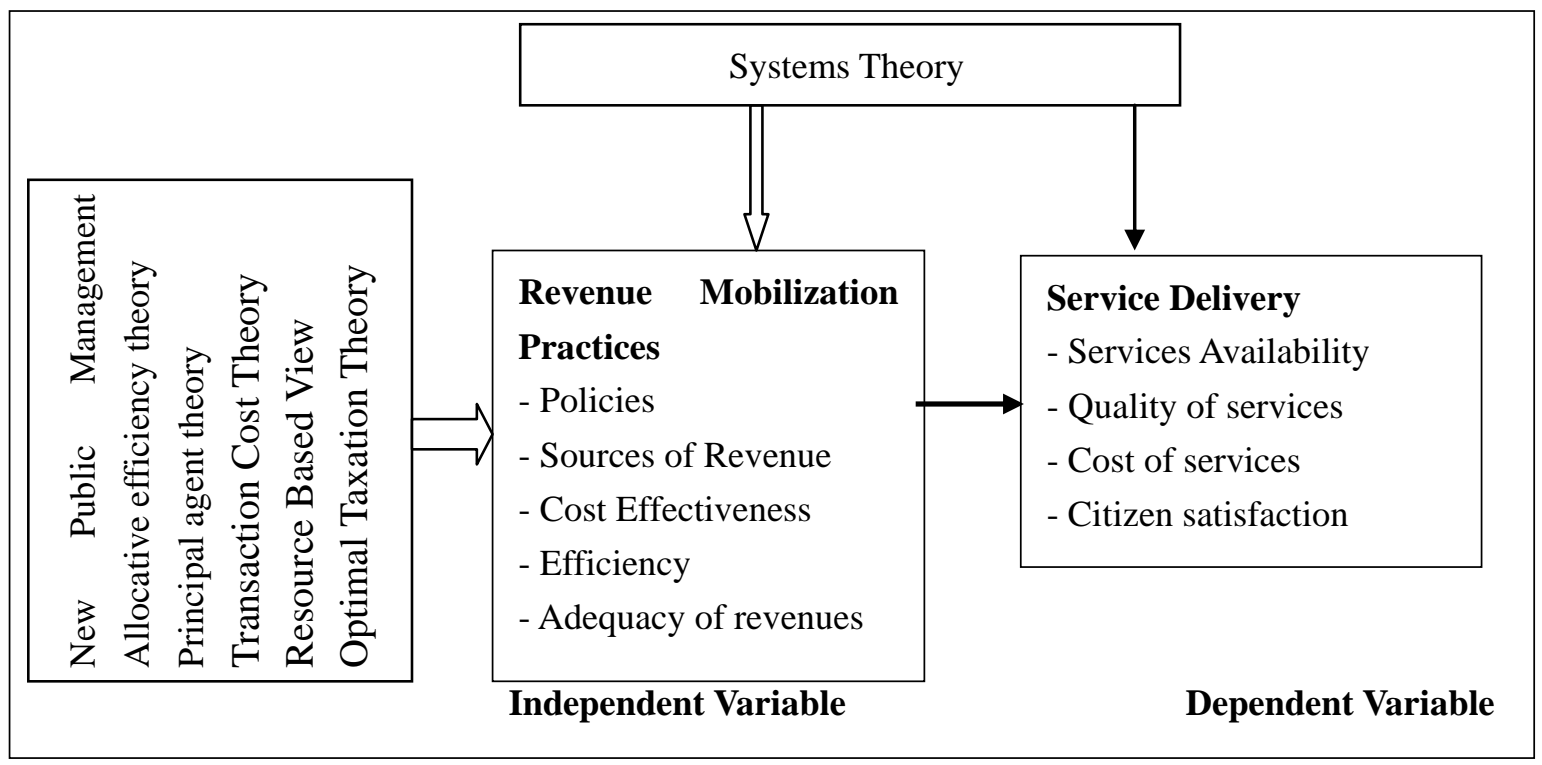

Figure 1. Conceptual Framework for Revenue Mobilization and Service Delivery

Source: Scott (2018) based on various views from literature. 


\section{Methodology}

The study was conducted within the pragmatic research philosophy and using mixed method research design where both quantitative and qualitative tools were used. These tools were used because the study tested a research hypothesis and had to provide deeper explanations into revenue mobilization practices and their influence on service delivery. The study utilized research questionnaire to gather quantitative data, while qualitative data were gathered using interviews and focus group discussions. The quantitative items on the research questionnaires were probed further through the interviews, key informants and focus group discussions. According to Mangan, Lalwani and Gardner (2004), methodological triangulation and using mixed methodologies increasingly provide multidimensional insights into diverse research problems. In this study, the correlational design was applied to depict the accurate linkage between revenue mobilization practices to service delivery in the DAs of Ghana.

The study population was the 170 DAs that were in existence in Ghana as at 2008 with a population of 23.11 million. The study used multistage sampling to pick its respondents. First, $20 \%$ proportionate sampling was applied to select 34 DAs from the ten geographical regions of Ghana. These were representative of the diverse characteristics of the DAs in Ghana based on factors such as; location, rural-urban, and poverty levels. Based on these 34 DAs, two DA officials from each of the nine key departments in each DA were selected yielding a total of 612 respondents.

Convenience sampling was applied to select 30 citizen respondents from each of the 34 sampled DAs based on the Central Limit Theory, which brought the total number of citizen respondents to 1,020. Purposive sampling was applied to select participants for 28 key informants who comprised of officers from the national and regional levels whose work was directly related to revenue mobilization and service delivery of the DAs. Lastly, purposive sampling was used to select 20 focus group participants for the two focus group discussions based in Tema and Tamale. A total of 963 out of 1020 questionnaires from citizens and 443 out of 612 from the DA officials were retrieved. Descriptive statistics and regression analysis tools from Statistical Product and Service Solutions (SPSS) version 21 were used to analyze the data. The quantitative data was analyzed using descriptive statistics; percentages, mean scores, standard deviation, correlation and multiple regression technique, while qualitative data were analyzed using thematic summary analyses.

\section{Data Analyses and Discussions}

This section presents results relating to revenue mobilization practices and their interaction with service delivery in the DAs. Issues covered in these discussions include the following:
a. Sources of Revenue for the District Assemblies
b. Procedures for Revenue Mobilization
c. Rating of Revenue Mobilization Practices
d. Policies guiding Revenue Mobilization Practices 
e. Link between Revenue Mobilization and Service delivery

f. Revenue Mobilization Influence on Service delivery.

g. Results of the Hypothesis Test

\subsection{Sources of Revenue for District Assemblies}

First, the study sought the awareness levels of respondents with regard to the various sources of revenue for DAs. The results revealed that a majority of the citizens (82.6\%) stated that they were aware of the sources of revenue to the District Assemblies (DAs). Only 17.4 percent of the respondents indicated that they were not aware of the sources of revenue for DAs. The results show that more citizens are knowledgeable on matters related to financing of the DAs as payments of revenue touched on them directly. As noted by Oyugi (2000), there is the need for locals as taxpayers, to understand revenue mobilization issues to be able to demand for accountability. Citizens listed the following sources of DAs revenues they were aware of and the results are presented in Table 1.

Table 1. Sources of District Assemblies Revenue - Citizens

\begin{tabular}{l|l|l}
\hline Sources of Revenue & Frequency & Percent \\
\hline Property Rate & 236 & 28.8 \\
\hline Basic Rate & 146 & 15.2 \\
\hline Tolls & 209 & 21.7 \\
\hline Assemblies Common Fund & 324 & 33.6 \\
\hline Others & 7 & 0.7 \\
\hline Total & 963 & 100.0 \\
\hline
\end{tabular}

Source: Field Survey, Scott (2014)

The results show that 33.6 percent reported that they were aware of District Assemblies Common Fund (DACF) while 28.8 percent were aware of the property rate. Twenty one percent were aware of tolls whereas 15.2 percent reported that they were aware of the basic rates as sources of revenue for the DAs. The study established that the District Assemblies of Ghana have various sources of funding some of which were not known to the citizens. World Bank (2011), cited in Betley et al. (2012) for example clarifies that District Assemblies could benefit from direct sources from the ministries, departments and agencies to finance deconcentrated and delegated functions such as Health and education. There are also other statutory funds such as the GetFund and the Road Fund. However, the most important fund is the DACF. District Assemblies (DAs) also generate internal funds through the mobilization of various tax and non-tax revenues. The DA officials also listed the sources of revenues for the DAs they were aware of as shown in Table 2. 
Table 2. Sources of DAs Revenues - DA Officials

\begin{tabular}{l|l|l}
\hline Sources & Frequency & Percent \\
\hline HIPC Funds & 95 & 21.4 \\
\hline Internally Generated Revenue (IGR) & 229 & 51.7 \\
\hline District Assemblies Common Fund & 111 & 25.1 \\
\hline Others & 8 & 1.8 \\
\hline Total & 443 & 100.0 \\
\hline
\end{tabular}

Source: Field Survey, Scott (2014)

The study findings in Table 2 indicated that 51.7 percent of the responding DA officials revealed that internally generated revenue was one of the sources of funds. Further results established that 25.1 percent indicated that there was a District Assemblies Common Fund while 21.4 percent indicated that Highly Indebted Poor Country (HIPC) Funds was also a source of funds to the Assembly. Additionally, the study enquired from the DA officials the main generators of internal revenues.

Table 3. Main Sources of Internal Revenues for District Assemblies

\begin{tabular}{l|l|l}
\hline Generators & Frequency & Percent \\
\hline Property Rate & 193 & 43.6 \\
\hline Basic Rate & 92 & 20.7 \\
\hline Tolls & 147 & 33.2 \\
\hline Others & 11 & 2.5 \\
\hline Total & 443 & 100.0 \\
\hline
\end{tabular}

Source: Field Survey, Scott (2014)

The results revealed that property rate was the major source of internally generated revenue. This was indicated by 43.6 percent of the DA officials. On the other hand, 33.2 percent of the responding DA officials indicated that tolls were the major source of internally generated revenues, while 20.7 percent indicated that basic rate was the major internally generated revenue. These findings concur with the observation of Akpa (2008) that revenue from different sources is a necessary tool for the effective functioning of any government machinery and that no government agency can survive without adequate revenue. This finding is also in sync with Bhatia's (2009) position that taxes from different sources should be levied by the government to enable it to serve the people and carry out its statutory obligations. However, the allocative efficiency theory according to Badunenko et al (2008) posits that these revenues must be allocated efficiently among the competing needs for them to enhance community well-being. Collection of revenues from different sources does not in itself lead to equity in provision of public service. Authorities must ensure that these revenues are optimally and efficiently allocated to have an impact on service provision to the community. 


\subsection{Procedures for Revenue Mobilization}

The study proceeded to request the citizens to list the procedures regarding DAs revenue mobilization with the results shown in Table 4.

Table 4. Proposed Procedures for Revenue Mobilization

\begin{tabular}{l|l|l}
\hline Procedures & Frequency & Percent \\
\hline Through their own Staff & 168 & 17.4 \\
\hline Through Revenue Contractors/Agents & 301 & 31.3 \\
\hline Both & 480 & 49.8 \\
\hline Any Other & 14 & 1.5 \\
\hline Total & 963 & 100.0 \\
\hline
\end{tabular}

Source: Field Survey, Scott (2014)

According to 49.8 percent of the respondents, the DAs should utilize an approach where both the DAs staff and agents are involved in revenue collection. On the other hand, 31.3 percent of the respondents held that the DAs should use revenue contractors/agents only, while 17.4 percent indicated that they should use own staff. As observed by Kimutai (2017), decentralized government units must carefully consider which revenue mobilization mechanism to utilize to ensure efficiency. Mrutu and Mganga (2016) advise that the revenue mobilization should take into consideration the costs and the perception of the taxpayers to enhance compliance levels.

\subsection{Rating of Revenue Mobilization Practices}

The study asked the citizen respondents to rate the revenue mobilization practices in the DAs. This analysis was based on a four point rating scale (1-Very Inefficient, 2- Inefficient, 3-Efficient and 4-Very Efficient). The results are shown in Figure 2.

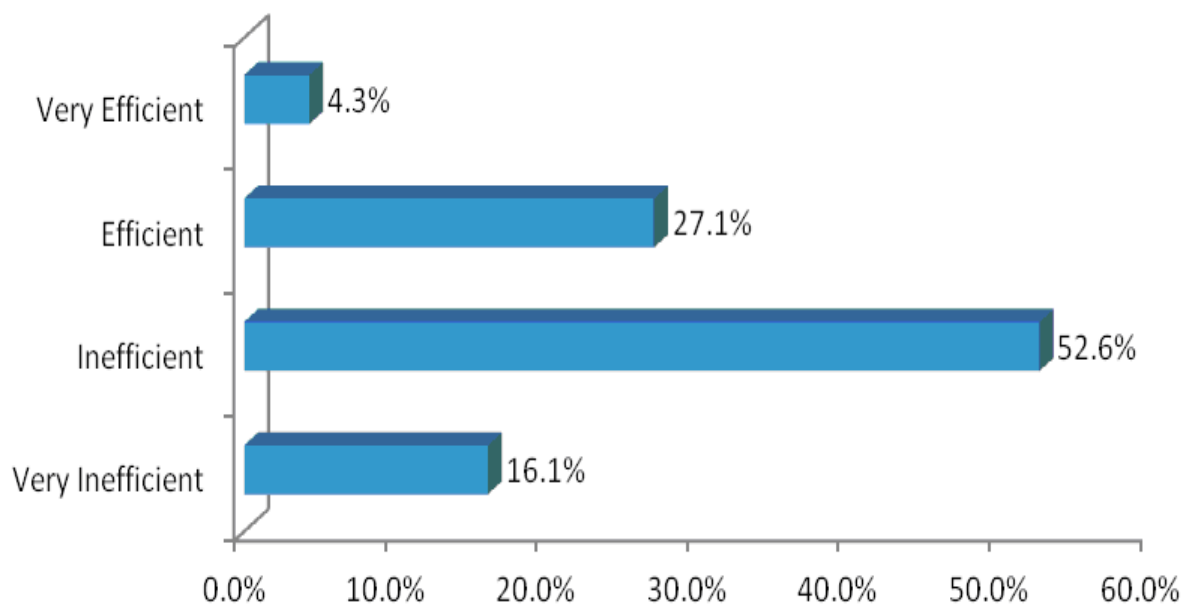

Figure 2. Rating of Revenue Mobilization Practices

Source: Field Survey, Scott (2014) 
According to majority of the citizens $(68.7 \%)$, the existing revenue mobilization practices were inefficient and very inefficient. On the other hand, 31.4 percent indicated that the existing revenue mobilization practices were efficient and very inefficient. These findings are in line with several scholars (including Adu-Gyamfi, 2014; Mrutu \& Mganga, 2016; Kimutai, 2017) who found complexities and inefficiencies in revenue generation practices of decentralized government units. These authors had further observed that, for DAs to be able to serve citizens well, they need to have innovative sources of revenue and efficient revenue mobilization mechanisms. The conceptual framework had depicted that efficiency of revenue mobilization practices is crucial in enhancing its role in influencing service delivery. Revenue mobilization practices in the DAs surveyed lacked the necessary efficiencies.

The study further sought the DA officials' ratings of the revenue mobilization practices in the district assemblies.

Table 5. Rating on Revenue Mobilization Practices by DA Officials

\begin{tabular}{l|l|l}
\hline Rating & Frequency & Percent \\
\hline Very Inefficient & 82 & 18.5 \\
\hline Inefficient & 147 & 33.2 \\
\hline Efficient & 202 & 45.6 \\
\hline Very Efficient & 12 & 2.7 \\
\hline Total & 443 & 100.0 \\
\hline
\end{tabular}

Source: Field Survey, Scott (2014)

The results in Table 5 showed that more than half $(51.7 \%)$ rate the existing revenue mobilization practices at the District Assemblies as inefficient. On the other hand, 48.3 percent of the DA officials revealed that the existing revenue mobilization practices were efficient or very efficient. Commenting on some of the inefficiencies of revenue mobilization, the DA officials mentioned that;

"some of the amount charged is so low and even that, people are unwilling to pay"

Comparatively, it emerged that citizens rated revenue collection practices as inefficient while DA officials rated revenue collection practices as efficient. Andrews, Boyne, Law and Walker (2008) depict that in most cases the public officials and citizens usually disagree on the efficiency of public administration/management practices and service delivery levels. Moreover, this can be viewed as a conflict as per the agency theory arguments by Leruth and Paul (2006), where the principal (citizens) have a conflict with the agents (DAs) regarding perception of efficiency of their PFM practices. The conflicting findings can also be understood from the perspective that DAs collect levies and rates from the citizens. Rigorous and efficient revenue mobilization would mean the DAs are collecting a lot of money from the citizens and this could lead to an outcry from groups such as traders, civil societies and politicians (Rees \& Hossain, 2010). 


\subsection{Policies Guiding Revenue Mobilization Practices in the DAs}

The study then enquired from the DA officials on procedures or policies which guide the revenue mobilization practices in the DAs. The results indicate that majority of the DA officials $(89.2 \%)$ revealed that there were laid down procedures to guide the revenue mobilization practices in the District Assemblies. However, 10.8 percent of the respondents indicated that DAs did not have laid down procedures to guide the revenue mobilization. These findings are aligned with Fosu and Ashiagbor's (2012) position that the most important aspect in revenue collection for devolved units is to have policies and procedures that guide the revenue collection practices.

On enquiry on whether the policies guiding revenue mobilization were uniform across the DAs in Ghana, majority of the DA officials $(68.8 \%)$ indicated that the policies were uniform. However, 31.2 percent indicated that the policies were not uniform to all District Assemblies. Uniformity of policies across similar decentralized units according to Fosu and Ashiagbor (2012) is an important starting point in ensuring that the revenue mobilization practices are not marred with malpractices and illegalities. As noted by Siswana (2007), uniformity of policies also allows easy comparative auditing as well as accounting and financial reporting by the oversight bodies.

Participants in the two focus group discussions at Tema and Tamale indicated that in many DAs, revenue mobilization had improved tremendously, especially for the internally generated Revenue (IGR) due to effective policies and mechanisms put in place by the assemblies. For example, it was cited that in the Tamale Metropolitan Assembly, officers who collected revenue on daily basis were made to send money to bank immediately, and submit the pay-in slips to the account's office at the assembly. Serial numbers of booklets were written against each collector's name to ensure effective monitoring. This system had improved revenue collection and the cost of collection had also been found to be effective.

These findings from the two focus group discussions correspond with the transaction cost theory as explained by Khan and Hildreth (2004), who indicate that, organizations should focus on developing their structures and processes with a view to improving institutional development and efficiency. The sentiments from the Tamale's focus group discussion indicated that DAs had put in place measures to improve revenue collection efficiency and reduce corruption by revenue collection officers. These measures are expected to lead to more equitable revenue collection and administration.

The participants in the Tema focus group discussion however, argued that, to further improve the IGR, there is the need to periodically reshuffle revenue and accounts officers, undertake further training and capacity building for the revenue collectors, as well as institute effective monitoring systems. Community education and creating public awareness on the importance of paying the property rate and other taxes promptly to the DAs were other areas which were noted to be deficient.

A finance officer based in Tamale noted that

in some of the revenue collection aspects, the cost of mobilization is higher than the revenue collected'. 
There were suggestions in the Tema focus group discussion, that, the Assemblies should continuously and aggressively diversify and look for other sources of revenue as the funds from government transfers were inadequate. This is in line with various authors (Akorsu, 2015; Fosu \& Ashiagbor, 2012; Mogues \& Benin, 2012; Rao, 2013) who have pointed out the weaknesses in the revenue mobilization practices of decentralized units and the need for reforms.

These results from the two focus group discussions were also like the results by Ola and Tonwe (2005) who noted that, inadequate financing and revenue collection capabilities remain a major challenge to the success of decentralization in many African countries. Similarly, Latema (2013) notes that many of the devolved units face the challenge of mobilizing appropriate levels of revenue to enable effective service provision and address poverty and inequality issues at the local level. However, Latema notes that for the citizens to be compliant with devolved units' revenue collection obligations, the devolved units must demonstrate effectiveness in applying the collected funds to projects with tangible benefits.

\subsection{Link between Revenue Mobilization and Service Delivery}

The study sought information on the link between revenue mobilizations and service delivery using a Likert scale containing statements measuring link between the two. The link between the revenue mobilization practices and service delivery were measured on a five-point Likert scale (1-Strongly Disagree, 2-Slightly Disagree, 3-Neutral, 4-Slightly Agree and 5-Strongly Agree). They were analyzed using percentages and presented in Table 6.

Table 6. Revenue Mobilization and Service Delivery Link in Percentages

\begin{tabular}{l|l|l|l|l|l}
\hline Statements & 1 & 2 & 3 & 4 & 5 \\
\hline $\begin{array}{l}\text { Revenue collection by the DA from residents } \\
\text { is cost effective }\end{array}$ & 10.5 & 21.3 & 17.6 & 33.0 & 17.6 \\
\hline $\begin{array}{l}\text { Residents in the DA do not complain of } \\
\text { revenues obtained from them }\end{array}$ & 34.6 & 24.4 & 15.8 & 14.4 & 10.8 \\
\hline $\begin{array}{l}\text { There are specific revenues mobilized for } \\
\text { specific service provision }\end{array}$ & 20.6 & 12.7 & 23.3 & 23.3 & 20.1 \\
\hline $\begin{array}{l}\text { There are conflicts between central } \\
\text { government and the DAs in revenue } \\
\text { mobilization }\end{array}$ & 31.7 & 18.6 & 21.7 & 14.8 & 13.2 \\
\hline $\begin{array}{l}\text { Revenues generated by DA are adequate for } \\
\text { service provision }\end{array}$ & 53.2 & 15.4 & 6.7 & 11.5 & 13.2 \\
\hline
\end{tabular}

Source: Field Survey, Scott (2014)

The study results indicate that 53.2 percent of the District Assembly officials strongly disagreed that revenues generated by District Assemblies were adequate for service provision. This agreed with Adu-Gyamfi (2014) who found that funds were inadequate for the Upper Denkyira East Municipal Assembly. The study results also indicate that 34.6 percent of the DA respondents strongly disagreed that residents in the DA do not complain of revenues 
obtained from them. These findings indicate that respondents complained of the levies charged by the DAs. These findings are consistent with those of Misch et al. (2011) who found that levies by devolved units were perceived as exorbitant, unfair and unjust by the citizens.

The study's conceptual framework had indicated that for revenue mobilization to positively influence service delivery, there needed to be harmony in revenue mobilization practices, and the mechanisms applied needed to be efficient and adequate revenue collected. However, the findings indicated that revenues generated by DAs were inadequate and there were inefficiencies and conflicts between central government and DAs in revenue collection.

Mean scores and standard deviation were calculated to verify the strength of the earlier percentages results analyzing the link between revenue mobilization and service delivery as shown in Table 7.

Table 7. Revenue Mobilization and Service Delivery Link - Means and Standard Deviations

\begin{tabular}{l|l|l}
\hline Statements & Mean & $\begin{array}{l}\text { Std. } \\
\text { Deviation }\end{array}$ \\
\hline Revenue collection by the DA from residents is cost effective & 3.14 & 1.22059 \\
\hline Residents in the DA do not complain of revenues obtained from them & 2.28 & 1.25746 \\
\hline There are specific revenues mobilized for specific service provision & 2.97 & 1.36441 \\
\hline $\begin{array}{l}\text { There are conflicts between central government and the DAs in } \\
\text { revenue mobilization }\end{array}$ & 2.45 & 1.30931 \\
\hline Revenues generated by DA are adequate for service provision & 1.99 & 1.35693 \\
\hline
\end{tabular}

Source: Field Survey, Scott (2014)

The results show that the District Assembly officials disagreed that revenues generated by District Assemblies were adequate for service provision; and that residents in the DAs do not complain of revenues obtained from them. This is shown by mean scores of 1.99 and 2.28 respectively on the Likert scale. The DA officials were however neutral on whether there were specific revenues mobilized for specific service provision and on whether revenue collection by the District Assemblies from residents was cost effective as shown by a mean of 2.97 and 3.14 respectively.

\subsection{Revenue Mobilization Influence on Service Delivery}

The study also sought to find from the DA officials the extent to which revenue mobilization influenced service delivery. This was measured on a five-point rating scale (1-Very Low Extent, 2-Low Extent, 3-Moderate Extent, 4-High Extent and 5-Very High Extent). 


\section{Macrothink}

Journal of Public Administration and Governance

ISSN 2161-7104

2018, Vol. 8, No. 4

Table 8. Extent to which Revenue Mobilization Influence Services - DA Officials

\begin{tabular}{l|l|l}
\hline Rating & Frequency & Percent \\
\hline Very Low Extent & 34 & 7.7 \\
\hline Low Extent & 79 & 17.9 \\
\hline Moderate Extent & 142 & 32.1 \\
\hline High Extent & 103 & 23.3 \\
\hline Very High Extent & 84 & 19.0 \\
\hline Total & 442 & 100.0 \\
\hline
\end{tabular}

Source: Field Survey, Scott (2014)

The results revealed that most $(32.1 \%)$ of the DA officials agreed that the revenue mobilization practices facilitate service delivery to a moderate extent. Those who indicated that revenue mobilization influenced service delivery to a very low extent were 7.7 percent.

\subsection{Hypothesis Testing for Revenue Mobilization and Service Delivery}

The study tested the hypothesis that revenue mobilization practices adopted by District Assemblies (DAs) in Ghana had a significant influence on service delivery. The various revenue mobilization practices included were; efficiency of collection procedures, adequacy of collected revenues and collection of revenues from a variety of sources. The weighted average of these practices was established. The dependent variable was service delivery which was a weighted average of various services including education, health, sports, infrastructure and agriculture among others. The results of the regression analysis are as indicated in Table 9, 10 and 11.

Table 9. Model Summary

\begin{tabular}{c|l|l|l}
\hline $\mathrm{R}$ & R Square & Adjusted R Square & Std. Error of the Estimate \\
\hline .126 & .016 & .014 & 10.88533 \\
\hline
\end{tabular}

a. Predictors: (Constant), Revenue mobilisation practices

Study results provided in Table 9 reveal that revenue mobilization practices explained around 1.6 percent of the variation in service delivery. This insinuates that 98.4 percent of the variation in service delivery is explained by other factors that were not incorporated in the model. This is justifiable since service delivery by government entities is affected by a variety of factors. 
Table 10. Analysis of Variance

\begin{tabular}{|c|c|c|c|c|c|c|}
\hline \multicolumn{2}{|c|}{ Model } & $\begin{array}{ll}\text { Sum } & \text { of } \\
\text { Squares }\end{array}$ & df & Mean Square & $\mathrm{F}$ & Sig. \\
\hline \multirow[t]{3}{*}{1} & Regression & 847.807 & 1 & 847.807 & 7.155 & .008 \\
\hline & Residual & 52135.824 & 440 & 118.491 & & \\
\hline & Total & 52983.631 & 441 & & & \\
\hline
\end{tabular}

a. Dependent Variable: Service delivery

b. Predictors: (Constant), Revenue mobilisation practices

The results in Table 10 provide the results of the analysis of variance. The findings indicate that the model was statistically significant $(\mathrm{F}=7.155 ; \mathrm{p}<0.05)$. This implies that the model can provide predictive ability when revenue mobilization practices are used to explain service delivery. Moreover, the results indicate that revenue mobilization factors in the DAs of Ghana can reliably explain the level of service delivery provided to citizens.

Table 11. Effect of Revenue Mobilisation Practices on Service Delivery

\begin{tabular}{|c|c|c|c|c|c|}
\hline & \multicolumn{2}{|c|}{$\begin{array}{l}\text { Unstandardized } \\
\text { Coefficients }\end{array}$} & \multirow{2}{*}{ 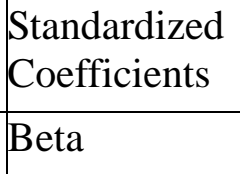 } & \multirow[b]{2}{*}{$\mathrm{t}$} & \multirow[b]{2}{*}{ Sig. } \\
\hline & B & Std. Error & & & \\
\hline (Constant) & 5.521 & .547 & & 10.086 & .000 \\
\hline $\begin{array}{ll}\text { Revenue } & \text { mobilisation } \\
\text { practices } & \end{array}$ & .063 & .024 & .126 & 2.675 & .008 \\
\hline
\end{tabular}

The findings presented in Table 11 reveal that revenue mobilization practices had a significant positive effect on service delivery by Ghana DAs $(\beta=0.063 ; \mathrm{t}=2.675 ; \mathrm{p}<0.05)$. The regression analysis results showed that revenue mobilization practices were positively and significantly related with service delivery. This shows that the revenue mobilization practices in the District Assemblies (DAs) significantly affected the levels of service delivery. The null hypothesis of no effect was therefore rejected.

The conceptual framework had depicted that revenue mobilization practices can have an influence on service delivery. The conceptual framework also had established certain prerequisites for revenue mobilization to play a role in influencing service delivery. These prerequisites included efficiency, harmony among collecting agents and adequacy of the collected revenues. The study results had indicated that 68.6 percent of the DAs viewed revenues collected as inadequate. Further, the study established that 68.7 percent of citizens held that revenue mobilization practices were inefficient while 51.7 percent of the DA officials indicated that revenue mobilization practices were inefficient. This inefficiency in revenue mobilization practices coupled with the inadequacy of the collected revenues related well with the poor ratings of service delivery. This may explain the significant effect of revenue mobilization practices on service delivery implying that when DAs enhance their revenue mobilization practices, service delivery is expected to improve. 
The finding of the study regarding significant and positive effect of revenue mobilization on service delivery agrees with findings from studies (Fosu \& Ashiagbor, 2012; Adu-Gyamfi, 2014) that many of the devolved units in Africa and in Ghana have poor revenue mobilization records mainly relying on financial transfers from the central government making them unable to providing satisfactory services desired by citizens within the devolved government units.

\section{Conclusions and Policy Recommendations}

The study concluded that revenue mobilization practices had a significant influence on service delivery. The study found that though DAs had various sources of revenue, they were inefficient in collecting the revenues which related to poor ratings in service delivery. The DAs had uniform laid down procedures to guide the revenue mobilization process, however these procedures were not always adhered to. Further, though revenue mobilization in the DAs had improved tremendously in recent times, revenues generated by District Assemblies were not adequate for service provision. Revenue collection was also riddled with inefficiencies and corruption. Adopting inefficient methods of revenue mobilization had therefore hindered DAs from providing the requisite services to the citizens.

The study recommends that, at the DA level, the DAs should audit and strengthen automation and appropriate technologies for better revenue mobilization and service delivery. Automation systems such as integration of mobile payment platforms in services such as parking and license payments will improve revenue collection and management while improving service delivery. In some of the revenue areas contracting out revenue mobilization would make the process efficient. DAs should improve the capacity of revenue staff and enhance the capacity of staff of other sections such as the accounting and internal auditing teams so that they can effectively utilize innovations and appropriate technologies to supervise and monitor revenue mechanisms and operations in the DAs. The Assemblies should also form, operationalize and strengthen revenue committees: A special revenue committee chaired by top officials such as the Coordinating Director could be set up to discuss and find solutions to some of the pertinent revenue problems.

The Assemblies should also push for legislative reforms to widen their revenue bases. Specifically, DAs should pursue mechanisms for bond financing which has become a prominent feature within local credit market. The model of bond financing ring fenced for specified projects could be explored.

At the national level, the study recommends that, the Minister of Local Government, the Head of Civil Service and Head of Local Government Service Secretariat (LGSS) should advocate for Constitutional amendment for bigger share of the District Assemblies Common Fund (DACF) and timely transfers to the DAs. Such amendments should also spell out sanctions to specific officials in case of delays and mishandling in the transfers. The national government should amend, review and consolidate existing Public financial management laws to ensure stiffer penalties and enforcement of sanctions on those involved in malpractices during revenue collection. The Ministry of Finance should support, and strengthen DAs in the integration and operationalization of technologies such as IFMIS by 
the DAs through legislation, budgetary allocation and staff capacity development. They should continuously audit and review the revenue systems of DAs for improvements.

Civil society should strive to create awareness on the importance of the citizens as the source of these revenues to support revenue mobilization efforts by the DAs. The citizens are encouraged to enhance their compliance to payment of business licenses and rates to enable the DAs provide efficient quality services which will lead to better quality of life for them. Compliance will also ensure the citizens and their businesses avoid legal tussles with the DAs.

\section{References}

Adu-Gyamfi, E. (2014). Effective revenue mobilisation by districts assemblies: A case study of Upper Denkyira East Municipal Assembly of Ghana. Public Policy and Administration, 2(1), 97-122. Retrieved from pparnet.com/journals/ppar/Vol_2_No_1_March_2014/7.pdf

Afoom, N. O. (2011). Impact of HIPC on poverty reduction in Ghana (2000-2008). Retrieved from http://dx.doi.org/10.2139/ssrn.1767829

Akorsu, P. K. (2015). An evaluation of the effectiveness of revenue mobilisation in the public sector of Ghana: The case of Cape Coast Metropolitan Assembly. International Journal of Economics, Commerce and Management, 3(1), 1-16.

Akpa, A. (2008). Public finance and budgeting: Issues, imperatives and challenges from Nigerian perspectives. Ibadan: Spectrum Books Limited.

Akudugu, J. A., \& Oppong-Peprah, E. (2013). Local Government Revenue Mobilisation and Management: the case of Asante Akim South District Assembly, Ghana. Journal of Public Administration and Governance, 3(2), 98-120. https://doi.org/10.5296/jpag.v3i2.3977

Andrews, R., Boyne, G. A., Law, J. \& Walker, R. M. (2008). Organisational strategy, external regulation and public service performance. Public Administration, 86(1), 185 - 203. https://doi.org/10.1111/j.1467-9299.2007.00695.x

Ayee, J. R. (1995). Financing sub-national governments in Ghana: The District Assemblies' Common Fund. Regional \& Federal Studies, 5(3), 292-306. https://doi.org/10.1080/13597569508420940

Badunenko, O., Fritsch, M., \& Stephan, A. (2008). Allocative efficiency measurement revisited-do we really need input prices? Economic Modelling, 25(5), 1093-1109. https://doi.org/10.1016/j.econmod.2008.02.001

Bahl, R. (1999). Fiscal decentralisation as development policy. Public Budgeting and Finance, 19(2), 59-75. https://doi.org/10.1046/j.0275-1100.1999.01163.x

Bahl, R., \& Solomon, D. (2003). Overview of the local government revenue system. In R. Bahl \& P. Smoke (Eds.), Restructuring local government finance in developing countries. Lessons from South Africa (pp. 71-93). Cheltenham, UK: Edward Elgar. 
Bardhan, P., \& Mookherjee, D. (2002). Relative capture of local and central governments: An essay in the political economy of decentralization. CIDER Working Paper No. C99-109. Berkeley: University of California

Baumann, P. (2000). Sustainable livelihoods and political capital: Arguments and evidence from decentralisation and natural resource management in India. London: Overseas Development Institute.

Betley, M., Bird, A., \& Ghartey, A. B. (2012). Evaluation of public financial management reform in Ghana 2001-2010: Final country case report. Oxford: Fiscu/Mokoro Ltd.

Bhatia, H. L. (2009). Public finance. New Delhi: Vikas Publishing House.

Bird, R. M., \& Slack, N. E. (2010). Taxing land and property in emerging economies: Raising revenue... and more. Toronto: University of Toronto Press. Retrieved from https://goo.gl/katjrj

Botchie, G. (2000). Rural district planning in Ghana: A case study (No. 21). IIED. Retrieved from pubs.iied.org/pdfs/7825IIED.pdf

Buertey, J. I. T., Miezah, A. K., \& Adjei-Kumi, T. (2013, August). Delays to large construction projects in Ghana: A risk overview. In S. Laryea, \& S. Agyepong (Eds.), Proceedings of 5th West Africa Built Environment Research (WABER) Conference (pp.235-245). Reading, UK: University of Reading

Chitere, P. O., \& Ngundo, V. M. (2015). Devolution as a means for self-governance: Its potential for poverty reduction in Kenya. Constitution, 3(1), 38-49. https://doi.org/10.13189/ijrh.2015.030105

Chitiga-Mabugu, M., \& Monkam, N. (2013). Assessing fiscal capacity at the local government level in South Africa (No. 201376). Retrieved from www.up.ac.za/media/shared/61/WP/wp_2013_76.zp39597.pdf

Coşgel, M. M., \& Miceli, T. J. (2009). Tax collection in history. Public Finance Review, 37(4), 399-420. Retrieved from https://doi.org/10.1177/1091142109331636

Crook, R. C., \& Manor, J. (1998). Democracy and decentralisation in South Asia and West Africa: Participation, accountability and performance. Cambridge, UK: Cambridge University Press. https://doi.org/10.1017/9780511607899

Finch, C. (2015). Participation in Kenya's local development funds: Reviewing the past to inform the future. World Bank Group, Washington, DC. Retrieved from https://goo.gl/oZNR7H.

Fjeldstad, O., Chambas, G. \& Brun J. (2014). Local government taxation in Sub-Saharan Africa: A review and an agenda for research. CMI Working Paper WP 2014: 2

Fosu, C., \& Ashiagbor, G. (2012). GIS Application for local government revenue mobilization. Proceedings of Global Geospatial Conference 2012 Québec City, Canada, 14-17 May. 


\section{Al Macrothink}

Journal of Public Administration and Governance ISSN 2161-7104 2018, Vol. 8, No. 4

Hamid, K. T. (2013). Good governance and new public sector financial management reform: A panacea, or placebo for transparency and accountability. A Paper Presented at the Executive Mandatory Professional Training Programme for Fellows of the Chartered Institute of Finance and Control of Nigeria (CIFCN), Abuja, Nigeria.

Hyman, D. N. (2013). Public finance: A contemporary application of theory to policy. Singapore: Cengage Learning.

Jang, S., \& Eger, R. J. (2018). The effects of state delinquent tax collection outsourcing on administrative effectiveness, efficiency, and procedural fairness. American Review of Public Administration. Retrieved from https://doi.org/10.1177/0275074018759435

Khan, A., \& Hildreth, W. B., (2004). Financial management theory in the public sector. Westport, CT: Praeger Publishers.

Kimutai, B. D. (2017). Revenue mobilization approaches and their influence on county socio-economic development in North Rift Region, Kenya. Doctoral Thesis. School of Human Resource Development, Moi University: Eldoret Kenya. Retrieved from http://ir.mu.ac.ke:8080/xmlui/handle/123456789/731

Latema, M. O. (2013). Business models for revenue generation and enhancement adopted by county governments in Kenya. Unpublished MBA Thesis, University of Nairobi. Retrieved from https://goo.gl/EasQyj

Leruth, L., \& Paul, E. (2006). A principal-agent theory approach to public expenditure management systems in developing countries. IMF Working Paper. Retrieved from SSRN: http://ssrn.com/abstract=934463

Livingstone, I., \& Charlton, R. (1998). Raising local authority district revenues through direct taxation in a low - income developing country: Evaluating Uganda's GPT. Public Administration and Development, 18(5), 499-517. https://doi.org/10.1002/(SICI)1099-162X(199812)18:5<499::AID-PAD39>3.0.CO;2-M

Mangan, J., Lalwani, C., \& Gardner, B. (2004). Combining quantitative and qualitative methodologies in logistics research. International Journal of Physical Distribution \& Logistics Management, 34(7), 565 - 578. https://doi.org/10.1108/09600030410552258

Misch, F., Koh, H-J., \& Paustian, N. (2011). SME taxation in Zambia. Lusaka: Deutsche Gesellschaft für Internationale Zusammenarbeit

Mogues, T., \& Benin, S. (2012). Do external grants to district governments discourage own revenue generation? A look at local public finance dynamics in Ghana. World Development, 40(5), 1054-1067. https://doi.org/10.1016/j.worlddev.2011.12.001

Mrutu, L., \& Mganga. P. (2016). Outsourcing or Giving All Out? Experience from Tanzania Local Government Revenue Collection. Macrothink Institute Journal of Public Administration and Governance, 6(3), 1-11. https://doi.org/10.5296/jpag.v6i3.8695 
Nkrumah, S. A. (2000). Decentralisation for good governance and development: The Ghanaian experience. Regional Development Dialogue, 21(1), 53-67.

Oates, W. E. (1998). On the welfare gains from fiscal decentralization. College Park, MD: University of Maryland. Retrieved from https://goo.gl/KIa211

Oduro, K. N. (2003). Results-oriented public expenditure management: Case study of Ghana. London: Overseas Development Institute.

Ojide, G. M., (2015). Federation account allocation in Nigeria: Implication for growth. Journal of Poverty, Investment and Development, 7, 8-11.

Ola, R. O., \& Tonwe, D. A. (2005). Local administration and local government in Nigeria. Lagos: Amfitop Nigeria Ltd.

Olowu, D. (2002). Introduction new public management: An African reform paradigm? Africa Development, 27(3), 1 - 16.

Oyugi, W. O. (2000). Decentralisation for good governance and development: The unending debate. Regional Development Dialogue, 21(1), 3-22.

Pauw, J. C., Woods, G., van der Linde, G. J. A., Fourie, D., \& Visser, C. B. (2010). Managing public money: A system from the South. Cape Town: Heinemann

Rakner, L. (2001). The politics of revenue mobilisation: Explaining continuity in Namibian tax policies. Forum for Development Studies, 28(1), 125-145. https://doi.org/10.1080/08039410.2001.9666160

Rao, M. G., \& Das-Gupta, A. (1995). Intergovernmental Transfers and Poverty Alleviation. Environment and Planning C: Government and Policy, 13(1), 1-23. https://doi.org/10.1068/c130001

Rao, S. (2013). Measuring the impact of PFM reforms on service delivery. GSDRC Helpdesk Research Report No. 946. Birmingham, UK: GSDRC, University of Birmingham. Retrieved from http://www.gsdrc.org/go/display\&type=Helpdesk\&id=946

Rees, C. J., \& Hossain, F. (2010). Perspectives on decentralisation and local governance in developing and transitional countries. International Journal of Public Administration, 33 (12-13), 581-587. https://doi.org/10.1080/01900692.2010.514459

Republic of Ghana. (1998). Auditor General's Report 1997. Accra: Ghana Publishing Company

Republic of Ghana. (1998). Serious Fraud Office Report 1997. Accra: Ghana Publishing Company

Republic of Ghana. (2000). Ghana, Auditor General's Report 1999. Accra: Ghana Publishing Company.

Republic of Ghana. (2011). Auditor General's Report 2010. Accra: Ghana Publishing Company. 
Republic of Ghana. (2014). Auditor General's Report 2010. Accra: Ghana Publishing Company.

Roberts, J. (2003). Managing public expenditure for development results and poverty reduction. London: Overseas Development Institute (ODI).

Rosen, H. S. (2004). Public finance. Heidelberg, NY: Springer: Springer US.

Salami, A. (2011). Taxation, revenue allocation and fiscal federalism in Nigeria: Issues, challenges and policy options. Economic Annals, 56(189), 27-50. https://doi.org/10.2298/EKA1189027S

Scott, G. K. (2016). Influence of public financial management practices on service delivery in Ghana's District Assemblies. Unpublished Doctoral Thesis. Institute of Development Studies, University of Cape Coast: Cape Coast, Ghana.

Scott, G. K. (2018). Accounting and Financial Reporting Practices as Tools for Service Delivery in The Public Service: The Case of Ghana's District Assemblies. Researchjournali 's Journal of Accounting, 6(1), 1-16. Retrieved from https://www.researchjournali.com/view.php?id=4257

Siswana, B. (2007). Leadership and governance in the South African Public Service: An overview of the public finance management system. Doctoral Dissertation, University of Pretoria, South Africa. Retrieved from http://repository.up.ac.za/handle/2263/28035

Smoke, P. (2001). Fiscal decentralization in developing countries: A review of current concepts and practice. Geneva: United Nations Research Institute for Social Development.

Thies, C. G. (2010). Of rulers, rebels, and revenue: State capacity, civil war onset, and primary commodities. Journal of Peace Research, 47(3), 321-332. https://doi.org/10.1177/0022343310361841

Torome, P. K. (2013). Relationship between revenue mobilization and performance of local authorities in Kenya. MBA Research Project. School of Business, University of Nairobi. Retrieved from erepository.uonbi.ac.ke/handle/11295/59275

World Bank. (2011). The role of public financial management for PRS Implementation. Retrieved from http://goo.gl/Zdm17Q

Yatta, F., \& Vaillancourt, F. (2010). 'Africa', in local government finance: The challenges of the 21 st century. Second Global Report on Decentralization and Local Democracy. Barcelona: United Cities and Local Governments.

\section{Copyright Disclaimer}

Copyright for this article is retained by the author(s), with first publication rights granted to the journal.

This is an open-access article distributed under the terms and conditions of the Creative Commons Attribution license (http://creativecommons.org/licenses/by/4.0/). 